\title{
Valencian Politicians under the spotlight of the À Punt TV network: A study of television coverage of the 2019 regional elections*
}

\author{
Àlvar Peris Blanes \\ UNIVERSITAT DE VALÈNCIA \\ alvar.perisДuuv.es \\ ORCID: 0000-0002-2323-2766 \\ Benjamín Marín Pérez \\ UNIVERSITAT DE VALÈNCIA \\ benjamin.marinßuuv.es \\ ORCID. 0000-0001-8957-7647 \\ Sebastián Sánchez Castillo \\ UNIVERSITAT DE VALÈNCIA \\ sebastian.sanchezRuv.es \\ ORCID. 0000-0003-3751-6425
}

Received: 10/02/2020

Accepted: 20/04/2020

\begin{abstract}
Despite repeated failures by the former Valencian television network - Canal 9 [Channel 9] to live up to its public broadcasting duties, the station's closure in 2013 still came as a shock. The step by the regional government (then run by the Conservative Partido Popular - PP) had a huge public impact, depriving Valencians of their public TV network at a stroke. That is why Valencian society had high hopes when a new public media platform - Punt Mèdia - was launched. Among other things, politicians and broadcasters needed to show that a more even-handed, professional approach could be taken to media reporting. The 2019 Regional Elections were a wonderful opportunity to prove this. On the one hand, it was a chance to use new audiovisual methods to better convey political information to citizens. On the other hand, it gave the network and its masters the chance to renounce the shameless political partisanship that had so marred Canal 9's history. This paper looks at the extent to which these goals were attained. It does so by examining $\dot{A}$ Punt's coverage of the election. Specifically, we focused on political interviews with candidates, and on the electoral debates. Various methodologies, both quantitative and qualitative, were used. We found that both the form and depth of news stories were fairly balanced. Nevertheless, the network showed a surprising lack of ambition despite À Punt's stated aspiration to be Valencia's leading TV station.
\end{abstract}

Keywords: regional elections, Valencian politics, À Punt, political interviews, electoral debates, 'infotainment'.

\footnotetext{
* This study falls within the framework of the "Strategies, Agendas, and Discourses in Electoral Cyber-Campaigns" R\&D Project [Estrategias, agendas y discursos en las cibercampañas electorales: medios de comunicación y ciudadanos] (Ref. CS02016-77331C2-1-R), granted by Spain's Ministry for the Economy and Competitiveness (MEC) for the period 2017-2020 and drawn up by the Mediaflows Research Group (www.mediaflows.es/en).
} 
Corresponding author: Àlvar Peris Blanes. Departament de Teoria dels Llenguatges i Ciències de la Comunicació. Facultat de Filologia, Traducció i Comunicació Avda. Blasco Ibáñez, 32 - 46010, Valencia (Spain).

Suggested citation: Perís Blanes, A. et al. (2020). Valencian Politicians under the spotlight of the $\dot{A}$ Punt TV network: A study of television coverage of the 2019 regional elections. Debats. Journal on Culture, Power and Society, 5, 67-84. D0I: http://doi. org/10.28939/iam.debats-en.2020-4

\section{INTRODUCTION: THE MEDIA AND POLITICAL CONTEXT}

À Punt Televisió (public TV network) began regular broadcasting on the $10^{\text {th }}$ of June 2018 after two months of test transmissions. This ended a stage that had begun in 2016 with the creation of Corporació Valenciana de Mitjans de Comunicació (CVMC) [Valencian Broadcasting Corporation] under Act 6/2016 of the $15^{\text {th }}$ of July and that continued with the beginning of Punt Ràdio broadcasts on the $11^{\text {th }}$ of December 2017 . The network's multimedia platform was launched a few days later on the $18^{\text {th }}$ of December under the name À Punt Mèdia. The first television broadcasts showed that the Valencian public broadcasting network had finally overcome the legal, employment, technical, and financial hurdles that had hitherto seemed insuperable.

The re-launch of public broadcasting brought to an end the period marked by the sudden, unilateral closure of Radiotelevisión Valenciana (RTVV) by the regional PP government in November 2013. The fall-out from that decision left a deep, collective scar. During the period in which there was no regional public broadcaster, most Valencians realised that with the odd exception, they counted for nothing when it came to TV and radio broadcasting. Quite simply, there was no one to tell the story of their successes and failures. It was even harder to find reports in Valencian on the television and radio, despite the tongue being one of the two co-official languages in The Valencian Country and, furthermore, spoken by roughly half of the region's population.

On the one hand, the RTVV's mission included fostering the Valencian audiovisual industry, which went through lean times after the network's closure. Some $\mathrm{AV}$ businesses went to the wall. There were several rea- sons for this. One was that the local audiovisual sector was over-cosseted by the RTVV. Another was the sheer inefficiency of policies for fostering the audiovisual sector, with lots of back-handers and favouritism. Certain firms and professionals (most of them from Madrid) took the lion's share of the work. When the public broadcasting corporation closed, it was not only the 1,600 people working in the network who lost their jobs but also many in ancillary sectors, with an additional 4,000 workers losing virtually their sole source of income overnight. This is without counting the hundreds of students and young professionals who suddenly faced bleak career prospects. Many left the industry for good (Peris Blanes, 2015).

Some have argued that the economic disaster RTVV became (what with the network's gross distortion of news, lack of plurality, and plunging audiences) were all part of a plot to discredit public broadcasting. The story is that there were plans to privatise it or to simply let it sink without trace (Col-lectiu Blasco, 2014; Xambó, 2013; Flors and Climent, 2013). During Spain's economic crisis in Spain, the notion grew - especially in Conservative circles - that public broadcasting was costing a fortune and could be scrapped so that the money could be spent instead on meeting citizens' basic needs. Back then, the discourse of those wishing to silence regional TV stations was that such public broadcasters were spendthrift, racking up huge deficits, and were poorly-managed if not downright corrupt. Such criticisms can still be heard today.

Since the idea of regional communication began to take hold in Spain some four decades ago (De Moragas, Garitaonaindía and López, 1999), many research studies have been carried out on the subject Marzal and Zallo, 2016; Marzal, Casero and Izquierdo, 2015; 
Francés, 2014; Zallo, 2011) calling for regional, county, and municipal radio and television coverage, whether through public broadcasters or through private ones. It is argued that such coverage is a benchmark of a societies' democracy. Such an approach has mainly been adopted in Northern Europe (Marzal and Soler, 2016: 123). From this standpoint, a good public communication service needs to be as highly prized as other planks in the Welfare State, such as Education and Health. Thus, a regional broadcasting system is not a waste of money but rather a social investment that boosts regional wealth.

There are many, diverse reasons why these regional and local broadcasters are prized. The first is that they provide an irreplaceable public service that both mirrors and trumpets social, cultural, linguistic, and institutional reality in Spain's regions, and in so doing, expresses the constitutional organisation of the Spanish State. Such an approach both helps articulate a region and fosters a feeling of belonging which in turn tends to boost both citizens' quality of life and social harmony. Second, it gives an impetus to a region's audiovisual industry and often powers innovation in both content and technology. Regional public audiovisual media have spawned talent and knowledge that has been exported to the rest of Spain and beyond. Furthermore, audiovisual output has given an economic boost to the hinterland it serves, supporting industry and companies in the area. Last but not least, it offers content that differs from producers elsewhere, both in terms of news and entertainment.

In this setting, the launch of $\grave{A}$ Punt raised high hopes in various sectors of Valencian society especially in the political sphere but also in the cultural and economic ones. Yet the launch took place in a fiendishly complex, highly-fragmented context, with 'free-to-air' content and 'pay content' available to all. The increasingly global nature of the industry made it ever harder to compete - a problem that was particularly acute for regional TV stations. The consolidation of OTT (Over The Top) audiovisual consumption platforms broadcasting continually over the Internet makes life tough for the mainstream media. Thus, for example,
Netflix, HBO, and Amazon Prime are transforming the audiovisual consumption habits of a big chunk of the population (Izquierdo-Castillo, 2017). Furthermore, the social media are creating, distributing, and consuming news and entertainment content, especially among young people (Conway et al., 2015).

According to Barlovento Comunicacíon (which bases its findings on data furnished by Kantar Media), the upshot of all this is that $\grave{A}$ Punt captured $2.1 \%$ of screen share during its first full year in which its audience was measured. This was $0.8 \%$ more than in the previous year but fell a long way short of forecasts. This was a poor result if one takes programming as a whole. Nevertheless, there were a few bright spots: the daily quiz show Atrapa'm si pots ['Catch me if you can'] (4.0\% of screen share for the 2019-2020 season); weekend 'docutainment' A córrer (4.9\% of screen share in the same period); the popular series L'alqueria blanca $(4.8 \%$ of screen share), also a hit during the RTVV period; NTC Migdia [Midday News] (5.9\%). Despite this last figure, some programmes occasionally gained high shares at moments when all eyes were on the news (for instance, during the torrential downpours that hit the region, and during the Fallas festivities). One of the criticisms levelled at the network is that it has failed to establish itself as the key source of news for The Valencian Country. From this standpoint, an electoral campaign offered a golden opportunity to boost viewing figures and show Valencian society that the new public broadcasting project is a great deal better than what was offered hitherto both in terms of content and style.

In any event, the low audience figures were scathingly criticised by the political opposition - basically PP and Ciudadanos - which accused the regional network of serving the interests of Valencia's Regional Government led by PSPV-PSOE and Compromís, with the support of Podemos. In fact, the accusation of bias was so strong that these opposition parties - Isabel Bonig, for PP, and especially Toni Cantó for Ciudadanos - often referred to À Punt as "TeleCompromís", insinuating that Compromís exercised political control over the TV network's staff and content, as if the situation were 
akin to that formerly found in RTVV. Going beyond political views, an audit report drawn up by GFK on the network's news programmes during the first quarter of 2019, the percentages of time given to the various politicians were: President Puig, with 78 appearance and $10.1 \%$ of the total - three times more than the Vice-President Mónica Oltra, who only appeared for $3.3 \%$ of the time, trailing the time given to PP's Isabel Bonig and Pablo Casado. Compromís chalked up the least speaking time, just a whisker behind Vox's 8.1\% of the total. By contrast, PP led in this category with $31.6 \%$. PSPV-PSOE had 30.5\%, Unidas Podemos had $14.4 \%$ of screen time, and Ciudadanos came last with $14 \%$. These data need to be weighed together with analysis of other political-content television formats.

The relationship between the media and politicians is a complex one. The concept of mediatisation (Hepp, Hjarvard and Lundby, 2015; Mazzoleni and Schulz, 1999) has been used to explain the negotiations carried out among the various social actors for establishing news priorities, taking for granted that — under given circumstances and in certain contexts - the media impose their production priorities, language, and pace on politics (Castelló, 2012). In other cases, it is politicians who pull the media's strings. In Spain, this negotiation follows a systemic dynamic that Hallin and Mancini (2004) term polarised pluralism, whereby Southern European media are heavily influenced by political parties. Some studies bear this out, especially in connection with election campaigns (Casero Ripollés et al., 2016; Valera-Ordaz, 2015). During election campaigns, the Central Electoral Board (JEC) stipulates that TV coverage of each political party must be directly proportional to the number of seats each party held in the previous legislature and parliament. This principle runs counter to journalistic criteria. That is why it is worthwhile analysing TV in the run-up to the campaign because this is when any media bias is more easily seen.

It is for these reasons that we consider À Punt's TV news coverage of the 2019 Valencian Regional Elections to be of special academic and social interest. Given that the run-up to the campaign has already been tackled by the aforementioned study, we shall focus on how the political interviews were conducted, and how the debate among the various presidential candidates for the Valencian Regional Government panned out.

\section{POLITICAL COMMUNICATION ON TELEVISION: BETWEEN INFORMATION AND ENTERTAINMENT}

Politics and its manifestations in the public arena are undergoing a deep transformation. Digital technologies (especially the Internet, social media, and mobile devices) have forever changed the way we relate to one another and how we socially organise (Shirky, 2008). Internet, for example, has become a dynamic ecosystem and fertile ground for grassroots participation, in which parties have lost sole control over political action, the media, and information. A radically different political culture is drawing on communitarian practices and collaboration given the enormous scope offered by digitalisation (Sánchez Duarte, 2016). Nevertheless, the new rules of the game remain fluid and it will take time before they become settled (López García and Valera Ordaz, 2017; Vaccari, 2013).

This transitional period of political communication exhibits hybrid features and is much more complex than the system that came before it (Chadwick, 2013). To this are added the changes and processes that have been under way for several decades, such as: (1) the blurring of the bounds between information producers and information consumers; (2) setting equal store by facts and opinions; (3) the confusion between what is public and what is private; (4) the disappearance of the distinction between information and entertainment (Delli Caprini and Williams, 2011; Mazzoleni, 2010). The last of these changes stems from the 'entertainment' approach taken to giving the news - the socalled hard news (Langer, 2000) - which involves a lot of showmanship in delivering the news discourse (Casero et al., 2017; Pellisser and Pineda, 2014) and the growing political content in entertainment programmes - especially in magazine slots and talk shows (Peris Blanes and López-Rico, 2017). This cross 
between information and entertainment has given rise to the term infotainment (Thussu, 2007; Brants, 1998) and that, in the case of politics, has been called political infotainment (Berrocal et al., 2014), pop politics (Mazzoleni and Sfardini, 2009) and more recently, as politainment (Berrocal Gonzalo, 2017).

These practices began to appear in the second stage of political communication (Blumler and Kavanagh, 1999) in the mid 1960s, coinciding with the modernisation of election campaigns (Norris, 2000). The clearest changes during this period went hand-in-hand with growing mediatisation (Mazzoleni, 2010). Among other things, there was growing professionalism in campaign organisation and communication, hence the rise of political advisors and 'spin-doctors' in the political and electoral marketing field, which became much more sophisticated and reached maturity (Maarek, 2009). At the same time, television became the key tool for conveying and legitimising the political message, in keeping with the importance of image in winning elections. In general terms, the demands and pace of television boosted showmanship and personalisation (Bennet, 2012), fragmenting political information both in and beyond election campaigns. In any event, given the medium's drama and leisure content, election campaigns naturally lend themselves to treating politics as an exercise in showmanship (Edelman, 1988).

Advertisements are the best-known form of TV propaganda so it is hardly surprising that these have become iconic features of modern election campaigns. Debates among the candidates have also become a key feature in TV coverage of campaigns (Canel, 2006). The fact that image is everything on TV means that news focuses on the candidate, pushing the party into the background. Politics is turned into a clash between leaders in a kind of electoral horse race (Maarek, 2009), with winners and losers and where political information is 'dumbed down' for mass audiences. This is why candidates' messages are simple and brief, on the lines of a military briefing or a sports commentary. Everything comes down to 'the sound bite' and raking over candidates' private lives - sometimes that often crosses the line into gutter-press sensationalism (Holtz Bacha, 2003). Such an approach is now par for the course in TV coverage of politics. In the third stage of political communication (the one we are currently in), election campaigns have become hyper-mediatised thanks to the digital revolution, which has boosted many of these practices and brought new ones into play.

In any case, 'infotainment' is a subject that is hotly debated by the experts. For some authors, these practices lead to a debasement and trivialisation of information, with citizens losing interest in what has become little more than a televised 'bear garden' (Langer, 2000). The outcome of such an approach is ever worsening mainstream TV coverage that focuses on the anecdotal and the superficial (Abril, 1997). Here, journalistic principles are thrown to the winds and flagship news programmes sink in the ratings and in the public's esteem (Redondo and Campos, 2015). In this respect, some authors have wondered whether 'infotainment' is a sign that journalism is giving way to economic interests. The 'commercialisation' thesis (McChesney, 1999) argues that the mainly economic view taken by the media is to blame for the changing approaches found on TV and radio, and the relentless rise of 'entertainment' in all networks' slots.

For others, the introduction of political content in entertainment, and the incorporation of entertainment in news coverage may 'empower' the population (Hartley, 2000). This is because many people who would not otherwise be interested in politics are better informed, share arguments and views, and become aware of how politics affects their daily lives. From this point of view, such content may play a democratising, liberating, and even an inclusive role (Harrington, 2008) given that it opens public debate to new actors and themes, lessening the deep disillusionment felt by some sectors of society (mainly the young and/or less educated). Furthermore, such authors argue that criticism of 'infotainment' overlooks the fact that the genre gives journalists a great deal of freedom (Benson, 2005). Indeed, Bolin (2014) argues that we are living in an age of hyper-journalism that has invaded 
new fields. Other authors prefer to sit on the fence, recognising the value of combining entertainment and information on the one hand, while arguing the need not to go overboard (León, 2010). The tensions between these approaches are clearly apparent in televised political interviews and election debates.

\section{The political interview on television}

TV interviews with politicians are a golden opportunity for viewers to discover political leaders' activities and proposals (Roca Cuberes, 2014). An interview is seemingly a collaborative venture but often the two speakers - interviewer and interviewee - form an asymmetric pair in which control over the interview is fought out between a powerful politician and a journalist hunting for a story or a headline. At this level, the interview becomes an exercise in negotiation, even if it is wrapped up in linguistic niceties (Cortés and Bañón, 1997). Here, a political interview is far from being a spontaneous encounter between journalist and politician. Instead, it is a meeting in which each party has clear, institutional objectives. Politicians are answerable to the general public and defend their deeds and political activities during the interview. The journalist assumes the mantle of a public representative, acting as middle-man. The questions asked by the journalists are supposedly of broad public interest (Bolin, 2014). The journalist's goal is to find out the details of the policies carried out by the politician and the party or government he represents. The interests of the two people in the interview are therefore at odds and it is not unusual to see sparks fly.

TV interviews with politicians were initially popular on private stations and were later taken up by public service broadcasters, given that the content can be broadly construed as being in the public interest (Wieten and Pantti, 2005). Nevertheless, there are differences in approach, depending on who owns the channel, and on criteria regarding balance and neutrality. Accordingly to Montgomery (2008), the classic form taken by a political interview can be described as a "rendering of account", which is perfectly reflected in the so-called 'turn system' (Heritage and Greatbatch, 1991). This practice is based on two basic features of modern journalism: (1) neutrality or 'neutralism' as Clayman (1992) would have it; (2) adversarialism (Clayman and Heritage, 2002). Neutrality in interviews is based on precepts that are hard to pin down (Pomerantz, 1984; Heritage and Clayman, 2010). Sometimes, the journalist asks complex, delicate questions in order to drag third parties into the interview. It is possible to tread the fine line between neutrality and adversarialism but sudden interruptions from either side can easily lead to open hostility.

From this standpoint, in both kinds of interviews, companies whether public or private tend to generally adopt neutrality and adversarialism and this guides the way journalists behave. That said one can see a marked tendency to abandon or undermine these rules on commercial channels - something that is not seen on public TV programmes ${ }^{\mathbf{1}}$ (Roca Cuberes, 2014). In any case, the commercial TV stations also use the formulas, follow-up questions, challenges, preferences and so on that are associated with classic political interviews. Be that as it may, scholars continue to hotly debate the two alternative trends or editorial lines. Various studies highlight the financial aspect of TV political interviews and thus the tendency to put advertisements first and the public interest second. Such programmes have frequent advertising slots and form part of the entertainment output - a format that keeps advertisers happy but which is to the detriment of the public interest and makes it that much harder for audiences to follow the thread of the political argument. By contrast, other writers stress the media's growing freedom, which is also seen in interviews where journalistic interests prevail over political and economic ones (Marchetti, 2005).

\section{The electoral debates}

Political debates are becoming a key element in election campaigns and are expected by citizens (Maarek,

1 Translator's note: While this is true of Spanish public broadcasters, it clearly does not apply to some other countries (the UK's BBC has become something of a repeat offender in breaching its Royal Charter in this respect). 
2009). It is almost as if such debates have become ritual events that legitimise arguments and candidates (Mazzoleni, 2010). In many cases, these debates have become the high point of the campaign, or at least, the most spectacular, and upon which media and public attention focus. That is why they are so important in shaping public opinion (Peris Blanes et al., 2017), influencing how votes are cast, and in making 'swing voters' swing one way or the other (Barreiro, Pereira and García, 2015). Accordingly, election debates are like an arena in which the various political players slug it out like the gladiators of old. These events boil down to building a media agenda, giving voice to citizens concerns, winning over the public, and boosting public interest in politics for the short life of the election campaign (López García et al., 2018; Humanes, 2014).

This is why TV political debates are big media events (Dayan and Katz, 1995) both in terms of audience numbers - with over $60 \%$ of screen share (García, 2015) - and in the amount of information they spawn (news, commentaries, analysis that feed other content in press, radio, television, and - increasingly - the social media). The importance of these debates does not solely lie in the TV audience but also in how they trickle down to diverse population segments. They provide a perfect example of how 'old' and 'new' media metaphorically copulate and replicate, turning the public into both onlookers (voyeurs) and participants (bedfellows), coupling multiple communication platforms - such as a second screen which many use with TV and Twitter (Vaccari, Chadwick and O'Loughlin, 2015).

As Mazzoleni (2010: 203-204) notes, there were precedents for election debates in the first stage of political communication. Yet they only became items of mass consumption during the presidential campaign between Kennedy and Nixon in The United States and this was quite simply because they were the first to be televised. Those debates personalised politics to an unheard of degree. They have been analysed ad nauseum from every angle (organisation; stage-setting; different kinds of formats, and so on). The Americans took a rigid approach, with advisors and 'spin doctors' thrashing out every last detail, including pauses, the order of questions, camera movements, and so forth. The European approach was more fluid and followed media canons, such as those applied in French presidential elections. Thus in France, participants can interrupt and answer, there are no fixed times, and the end result is more genuine and immediate but also more unpredictable - something that whets the public's interest. In those cases where the electoral system does not include a direct choice between two candidates, debates may include several contenders something that requires rules to ensure that everyone gets a fair crack of the whip.

This is what happened in Spain, which began to hold election debates in 1993, in which the same two candidates (Felipe González for PSOE, José María Aznar for PP) battled it out twice. This kind of debate, held between the two biggest parties, was repeated in 2008 and in 2011. However in 2015, election debates were held in several formats in a wholly new political setting (López García et al., 2018: 783). There was a one-on-one debate between the candidates of the two main parties (Mariano Rajoy for PP, and Pedro Sánchez for PSOE) but there was also a debate among the leaders of the four largest political parties (the 'classic' PP and PSOE plus two upstarts, Podemos and Ciudadanos). There was also a debate among the candidates of new parties, including minority ones such as Izquierda Unida, and in regional settings, Esquerra Republicana, and Partido Nacionalista Vasco [PNV, in Basque: Euzko Alderdi Jeltzalea - EAJ]. Those taking part in the final election debate were: Pablo Iglesias for Podemos, and Albert Rivera for Ciudadanos. It took place within the framework of the popular Salvados TV programme (La Sexta). In the Salvados debate, the programme's presenter, Jordi Évole, took the two candidates to a bar in a working-class area of Barcelona to conduct a more flexible, dynamic kind of debate (Peris Blanes et al., 2017). Since then, there were no more debates between just two candidates. Instead, debates featured four candidates in the June 2016 election, and five candidates in the April and November General 
Elections of 2019, this time incorporating Santiago Abascal of Vox. In the last three General Elections (one in 2016 and two in 2019), there were also debates between female candidates to ensure that the fairer sex were also given a political voice.

There were three broad differences between the first and the last debates (López García et al., 2018: 776777). The first was the sheer growth in the number of broadcasters given the sea change in Information and Communications Technology (ICT), with a plethora of new digital TV stations, and of Internet platforms with a long reach. Second, there was a rise in the number of parties with a chance of forming the next government. Third, there was the diversification of TV formats through which to present the dialectic clash of the candidates, along with the incorporation of infotainment-like approaches. However, some studies (López García et al., 2018) found that election debates in Spain generally act as discussion forums for covering sectoral and public policies - something that contrasts with the trend towards mediatisation in most other political communication contexts and forums. Television can affect the debate through the format chosen and the questions put. The questions are usually agreed with the guests beforehand yet the candidates are the protagonists and these can still give detailed answers if they so choose. One can therefore say that, in the debates - unlike in the highly mediatised activity surrounding them - politicians can still set their own agendas through the preceding negotiations (Couldry and Hepp, 2013).

\section{METHODOLOGY AND RESEARCH HYPOTHESIS}

To find out what À Punt's coverage of the April 2019 Regional Election was, we examined the political interviews and the election debate. Both are classic genres when it comes to media coverage of election campaigns. We considered that this approach would perfectly complement the study on the network's news coverage of the run-up to the election campaign. The aforementioned study was carried out by an external firm.
With regard to the interviews of political leaders, the degree of combativeness or lack of neutrality is key to determining whether a publically-owned corporation (such as $\grave{A}$ Punt) is acting in accordance with its democratic mandate. Depending on the findings, we can either question or rule out the use of public broadcasting for party political ends. In Spain, the interviewing of politicians must take place within a legal framework for journalism and for the media, both public and private. Nevertheless, one should recall that professional ethics and style manuals only provide guidance and are never legally binding. This means that Spanish television networks are not subject to any restrictions other than those set by the journalists themselves and the nation's legal framework (which in Spain's case, stems from The Constitution). In other words, journalism in Spain is governed by the media.

To this end, we analysed the following interviews of Valencian politicians conducted by $\grave{A}$ Punt. The interviews were with: (a) Ximo Puig, the President of Valencia's Regional Government (PSPV-PSOE candidate); (b) Mónica Oltra, the Vice-President of the Regional Government (Compromís candidate); (c) Isabel Bonig (PPCV candidate); (d) Toni Cantó (Ciudadanos candidate); (e) Rubén Martínez Dalmau (Unidas Podemos candidate). Each of the presidential candidates for the Valencian Regional Government was interviewed on two occasions, one on the programme L'entrevista, whose sole purpose is to interview a leader, and another interview on the news programme NTC Nit. The dates chosen for the interviews were as follows: Ximo Puig, 22/04/2019 and 04/03/2019; Mónica Oltra, 16/04/2019 and 05/03/2019; Isabel Bonig, 23/04/2019 and 07/03/2019; Toni Cantó, 15/04/2019 and 11/03/2019; Rubén Martínez Dalmau, 12/04/2019 and $27 / 03 / 2019$.

With regard to the electoral debates, we shall analyse the only debate held with the presidential candidates for the Valencian Regional Government. This debate was held at $\grave{A}$ Punt on the $25^{\text {th }}$ of April - Valencian Parliament Day - a symbolic date because it marked the anniversary of The Battle of Almansa. That battle was decisive in securing a Bourbon victory against the 
Hapsburgs in The War of The Spanish Succession. The Bourbon victory meant Felipe $\mathrm{V}$ became King of Spain. It also spelt victory for French-style Absolutism, the enactment of the Decreto de Nueva Planta [basically, an $18^{\text {th }}$ Century version of an 'Enabling Act']. That decree swept away age-old Valencian rights, autonomy, and self-government, only to replace it with the kind of highly-centralised (and often dictatorial) government that has marked the course of Spanish history over the last three centuries. Our analysis will focus on issues bearing on the debate format and the way it was televised. We also make a comparison with the two debates held by Spanish TV networks for the General Election (TVE, $22^{\text {nd }}$ of April 2019, and Atresmedia, 23 ${ }^{\text {rd }}$ April 2019). Last but not least, we shall make comparisons with the last electoral debate broadcast by the former public broadcasting network, Canal 9, for the 2011 Valencian Regional Election. Those taking part in the debate were the leaders of the political parties with seats in the Valencian Parliament.

Based on the foregoing considerations, we present the following research hypothesis and questions:

H1: The coverage of the 2019 Regional Election by $\grave{A}$ Punt was conventional, even though the new television network could (had it chosen to) have taken an innovative approach to the run-up to the campaign and the campaign itself.

C1: How neutral was the regional TV network in its interviews of politicians? Did it do its duty as a public service broadcaster in this respect or was there evidence of bias?

C2: What electoral debate format did À Punt adopt? Were the debates like the ones broadcast by State-wide media such as TVE and Atresmedia? Did À Punt innovate compared with its forerunner, Canal 9?

As to the methodology used, the ten interviews were announced using the classical studio, presented by one of the network's star journalists. The set and the positioning of the presenter and guests followed similar narrative lines. The number of questions posed varied slightly between programmes. Both Ximo Puig and Mónica Oltra were asked no fewer than 14 questions on each of the news programmes (A and B). Bonig and Martínez Dalmau were asked 13 questions apiece, and last, Toni Cantó was asked 12 questions in the first programme and 13 in the second one. To grasp the difficulty of each question asked, a 5-point Likert Scale (0-5) was used, in which 5 indicated the hardest question and 0 the easiest. To avoid errors arising from researcher subjectivity, all of the questions ( $\mathrm{n}=$ 133) were evaluated using two external coders who had not taken part in the initial coding. The result of the inter-coding (intercoder reliability) was $80.4 \%$, an acceptable value that exceeds the minimum considered valid for research in the Social Sciences (Neuendorf, 2002). SPSS V21 IBM software was used in the analysis using a qualitative approach that took into account all of the aforementioned elements.

\section{RESEARCH RESULTS}

\section{Televised political interviews}

Live audiovisual interviews of political leaders take in many internal and external factors. The internal factors are linked to the journalistic discourse on current affairs and editorial policy. The external factors cover such things as the setting, staging, and the audiovisual facilities for the interview. In televised political interviews, there are the principles of courtesy, neutrality, and co-operation in the face of deliberate control over the audiovisual discourse and its narrative elements. The term 'audiovisual courtesy' (Sánchez Castillo, 2018) alludes to a strategy adopted by the presenter in pursuing an audiovisual approach whereby he receives some of the guest's proposals favourably and other unfavourably. This study focuses not only on the semantic content of what the speaker says but also on the practical implications arising from certain audiovisual constructs, especially shots of the speaker, the intensity of the question, and audiovisual narrative resources (questions with split screen, questions with supporting video, the use of text - captions and so on). 
Table 1 Difficulty of Questions

\begin{tabular}{|r|c|c|c|c|c|c|}
\hline & N & Min. & Màx. & Sum & M \\
\hline A-Ximo P & 14 & 2 & 4 & 47 & 3.36 & .633 \\
\hline B-Ximo P & 14 & 2 & 4 & 44 & 3.14 & .663 \\
\hline A-M Oltra & 14 & 2 & 4 & 45 & 3.21 & .699 \\
\hline B-M Oltra & 14 & 2 & 4 & 46 & 3.29 & .611 \\
\hline A-I Bonig & 13 & 3 & 4 & 44 & 3.38 & .506 \\
\hline B-I Bonig & 13 & 3 & 5 & 49 & 3.77 & .599 \\
\hline A-Toni C & 12 & 2 & 4 & 40 & 3.33 & .651 \\
\hline B-Toni C & 13 & 2 & 5 & 44 & 3.38 & .870 \\
\hline A-R.M. Dalmau & 13 & 2 & 4 & 38 & 2.92 & .641 \\
\hline B-R.M. Dalmau & 13 & 2 & 4 & 34 & 2.62 & .650 \\
\hline Total: 133 & & & & & & \\
\hline
\end{tabular}

With regard to neutrality, after analysing the questions put to the political leaders, it was clear that there was little difference in the median values (Table 1). While the results themselves show no significant differences, the highest median fell to Isabel Bonig $(\mathrm{M}=3.77$; $\mathrm{SD}=.599$ ), who was asked harder questions with a stronger ideological bias. By contrast, the one with the lowest median was Rubén Martínez Dalmau (M = 2.62; SD = .650). On the other hand, Toni Cantó, the candidate for Ciudadanos, got a similar median $(\mathrm{M}=$ 3.38; $\mathrm{SD}=.870$ ), as did the candidate for Compromís, Mónica Oltra $(\mathrm{M}=3.29 ; \mathrm{SD}=.611)$. Here, one should note that the scores for the two biggest parties PSPV-PSOE and Partido Popular - were very similar, with barely 0.30 difference in their medians despite a tendency to favour Puig in the ' $\mathrm{B}$ ' interviews. It is worth analysing whether the low score obtained by the Unidas Podemos candidate was due to his lack of experience of government management - a reason why the questions he were asked were less incisive, especially in Interview ' $\mathrm{B}$ '. It is symptomatic that there was a difference of over a point between the ' $\mathrm{B}$ ' interviews of Bonig and Martínez Dalmau. The trend line in Graph 1 shows that the candidates received very even treatment over the 133 questions asked in the 10 programmes studied. This even-handed treatment applies both to the audiovisual discourse and the narratives arising from the programme. From a statistical standpoint, there is no significant correlation between a candidate and the questions he/she was asked $(\mathrm{r}(133)=.43 \mathrm{p}<.001)$.

In addition, one of the core aspects of this study focuses on the scene-setting and conduct of the interviews. The goal was to discover how audiovisual language panned out in the television age. The data we gathered lets us say that $\grave{A}$ Punt's audiovisual treatment of each of the regional political leaders was well balanced, with the guests being placed in very similar studio settings. The interviews were carried out in the studio, with tight control of the audiovisual discourse and thus the interview videos were more rigid than the campaign videos appearing on the news. Moreover, the programmes did not show any bias in the presentation of their guests. Although the motives behind 'audiovisual courtesy' go beyond the 


\section{Graph 1 Difficulty of Questions (median values)}

4

3.5

3

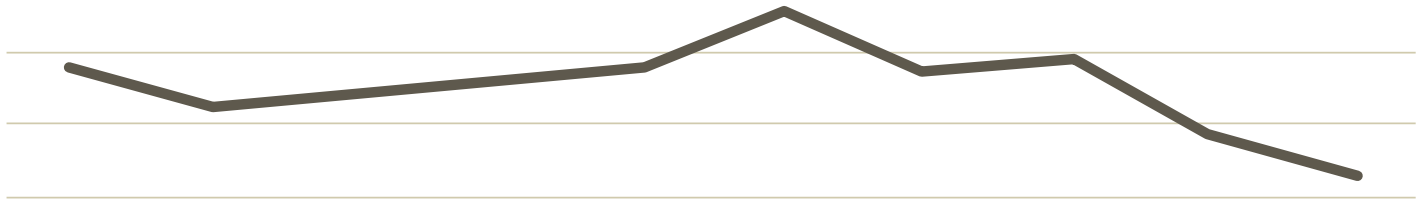

2.5

2

1.5

1

0.5

0

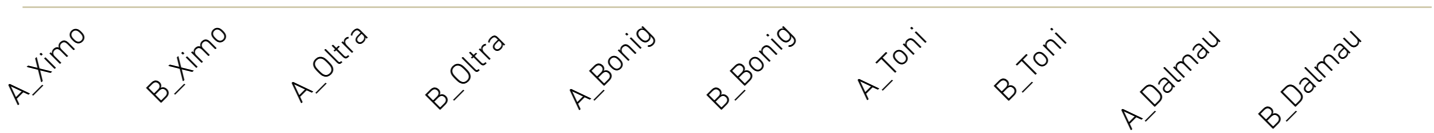

Source: The Authors.

scope of this study, there was no reason to think that the narrative approach changed as a function of the candidate's place in the political spectrum $(\mathrm{r}(10)=$ $-.29 \mathrm{p}<.001)$. The videos accompanying the campaign were broadcast as news items. This gave more scope for improvisation, especially in the run-up to the campaign when there were fewer strictures on what could be shown. All candidates were interviewed in the same studio settings and there were no significant differences in the resources deployed between one programme and another. The camera shots cued viewers for when the audience should mark the candidate's words. As Nimmo (1995) suggests, the political image projected during a campaign may strengthen, change, or upset the general public's pre-conceived ideas. The data gathered in our study leads us to say that all the candidates used their studio presence to enhance their image with the public.

As far as audience figures went, most of the interviews fell below the network's average viewing figures, with little difference between the programmes. One can highlight the poor audience figures for Oltra's inter- view, which was held on the $16^{\text {th }}$ of April 2019 at the height of the election campaign. She only chalked up a $1.0 \%$ screen share. By contrast, Martínez Dalmau chalked up a $3.3 \%$ screen share $(59,000$ viewers) on the $27^{\text {th }}$ of March. President Puig obtained a 1.9\% screen share for his interview of the $4^{\text {th }}$ of March, and 2.2\% in the interview of the $22^{\text {nd }}$ of April, just a week before the Regional Election. The figures are not especially relevant, even though it is generally considered an advantage to be interviewed last - particularly when the election is so near. In any event, the audience figures were so low that they were neither representative nor decisive.

\section{À Punt's one and only debate}

During the 2019 Regional Election, À Punt Mèdia only broadcast one TV debate with the candidates of those parties with seats in the Valencian Parliament (that is: PSPV-PSOE, PPCV, Compromís, Ciudadanos, and Podemos). This is why parties such as Vox and Pacma were left out of the debates. The date chosen to hold this debate was none other than the $25^{\text {th }}$ of April - Valencian Parliament Day. 
The debate, as is usual in Spain, was agreed with all the parties featuring in it (on this occasion, there were five). The debate itself was split into five large blocks, covering: (1) The Economy; (2) The Environment and Regional Government; (3) Regional Funding and Model of The State; (4) Social Policies; (5) Education and Research. Each thematic block lasted twenty minutes, with four minutes for each candidate. The candidates opening and closing each block were chosen at random. The candidate opening a block did so with a brief one-minute speech, while the candidate closing the block spoke for just thirty seconds. At the end of the debate, each candidate had a 'golden minute' in which to sum up his message for the general public. It was only during these three brief spells that the rest of the candidates were forbidden to interrupt. At the beginning of the programme, the moderator explained how the network wanted the debate to unfold. In general, the chosen debate format allowed intense discussion among the politicians.

Nevertheless, there were also flaws, such as the candidates being unable to interrupt directly but instead having to ask the moderator for permission to speak. This made the proceedings much less spontaneous and adversarial than one would expect of a TV debate. The rules covering whether one could or could not intervene confused some of the candidates. The rule on asking the moderator for permission to speak was intended to stop a candidate systematically interrupting one or more of his opponents. Yet in practice, there were several points during the debate in which candidates were clueless about whether they could speak with or without the moderator's permission.

Time control was another thorny issue during the debate given that it forced the moderator to constantly cut candidates off just when they were finishing their discourse. The format also forced candidates to respond very briefly to their opponents in $10-15$ second sound bites. This led to more than a few short, superficial answers to deeper questions (something that has become a hallmark vice in modern political communication). By contrast, the fact that candidates had to ask the moderator if they could take the floor, and were not obliged to answer their rivals was something they turned to their advantage. While the moderator repeatedly asked candidates to reply when a direct criticism was made, he was not always successful in getting them to do so.

Even with these glitches, the format often fostered a real debate among the five speakers (three men and two women). Yet it was not as lively as modern American or Spanish debates (for instance, the TVE General Election debate on the $22^{\text {nd }}$ of April 2019, and the Atresmedia one on the $23^{\text {rd }}$ of April 2019). Despite the rules and time control over each thematic block, there were more replies and counter-replies in these debates, which made the battle of ideas both more intense and absorbing. On those two networks, the candidates' dialectic thrusts and parries made for a much more attractive programme. That said, some analysts criticised the constant bickering, arguing that it forced the candidates to focus on anecdotal, superficial points.

In any event, the new Valencian public broadcasting corporation and its coverage of the election campaign broke with the kind of debates held by the earlier regional TV network. Thus the format adopted by $\grave{A}$ Punt owed nothing to that used by the old Canal 9 during its 24-year life. First, the Canal 9 debates were recorded, relieving the candidates from the stress of a live broadcast. Second, the old network's 'debates' were actually no more than a series of monologues, with the candidate staring at the camera. The old format gave no chance to challenge what he said. Last but not least, the programme format was linear, with no changes of camera shot until the candidate had ended his speech and the moderator gave the floor to another candidate to deliver his monologue.

By contrast with Canal 9's starchy, unimaginative approach, À Punt's format for the Regional Election did much to foster debate and featured a wide range of techniques. Thus there were shots in which one listened to the candidate, wide shots, cuts, close-ups, split screen showing the two candidates, modern graphics, and so on. Taken as a whole, À Punt's pres- 
entation was dynamic, with a well modulated pace providing a more complete, suggestive audiovisual tale for the audience. The programme was shot in Studio 2 at the Burjassot Programme Production Centre and was filmed live. It was preceded by a 40 -minute programme in which analysts strove to raise audience interest in the debate. The studio was given an avantgarde, neutral style in which greys, blues, and white predominated, with the candidates standing behind modern stands. There was no studio audience, in line with the modern Spanish approach to political debates (similar to the French and German models). This differs from the American model in which such debates follow a talk-show pattern (Marín, 2003). The lack of a studio audience made it easier for the candidates to concentrate. A studio audience would have put them under greater pressure, with the risk of them losing the thread.

With regard to impact, À Punt's broadcast fostered later news, given that the debate was not seen on TV but was also spread through radio, the Internet, and social media. The TV broadcast chalked up a $4.1 \%$ screen (75,000 viewers), which was above the network's average screen share (2.4\% at that time), and at some moments reached a $5.4 \%$ share $(250,000$ viewers). That was far less than the media impact of the two debates in the General Election on TVE (43.8\%) and Atresmedia (48.7\%), with TVE racking up over 9 million viewers and Altresmedia almost 9.5 million throughout Spain. The two networks' audience shares in The Valencian Country were $33.9 \%$ and $46.1 \%$, respectively. The gap between the two elections reveals the overlap in the two electoral processes in 2019 with a General Election and a Regional Election. In this case, there was more local interest in the General Election than in Valencia's regional one. In any case, one should not forget that $\grave{A}$ Punt had to compete with the TV fare served up to Valencian society in the context of a highly competitive media market. One should also bear in mind that just a year after the rebirth of a regional public broadcaster, the TV sets in many Valencian households had not been re-tuned to receive À Punt. Even so, the broadcast generated 10,000 tweets, with 1,500 participants, and 26 million impressions. Furthermore, it was the 'trending topic' in Spain with the hashtag \#DebatCortsÀPunt. This mass participation was made possible by the host of re-broadcasters in today's communication landscape. The amplification of messages through new channels gave the debate a much bigger social impact - something that also applies to election debates in Spain and in the wider world.

\section{DISCUSSION AND CONCLUSIONS}

À Punt's coverage of the 2019 Regional Election was the first by this public broadcasting network. That coverage was varied and drew on various news and entertainment genres to put over candidates' messages to citizens. Going beyond purely news programmes - whose election campaign coverage is subject to the strict rules of the Central Electoral Board (JEC) - the network also interviewed politicians and held an election debate featuring presidential candidates in the Valencian Regional Election. À Punt also invited candidates to attend one of its popular entertainment programmes - Assumptes Interns - but we shall consider this in forthcoming studies. With regard to H1, we argue that taken as a whole, $\grave{A}$ Punt's coverage was both conventional and appropriate.

À Punt's coverage was much better than the old Canal 9 TV station. This is because the latter used a variety of television formats - something that was especially true in the debates. With regard to political bias for or against a given candidate, $\grave{A}$ Punt's coverage was generally balanced. Although there was a hint of bias in interviews with some candidates on news programmes, it was not significant. In any event, it was a great deal more even-handed than the news coverage in the run-up to the campaign, in which PSPV-PSOE and PP (respectively headed by Puig and Bonig) came off better while Compromís came off worse. In that case, the two main parties benefited from the more generous time allocation the broadcaster was forced to give by virtue of the Electoral Act (as noted earlier, such allocation is based pro rata on the number of seats each party had in the previous Valencian Parliament). 
On the down side, the new network (launched in 2018 and thus the 'new kid on the TV block' in both Valencia and Spain) showed little innovation in its choice of news formats for putting over political messages. In this respect, its programmes were very similar to those of other Spanish broadcasters, whether regional or national. À Punt took no risks, while other networks considered debates of the kind seen in the Salvados series in 2015. Obviously such an initiative requires co-operation from politicians. Here, we have no way of knowing whether Valencian politicians declined more adventurous formats.

Maybe this is one of the reasons why Valencian society was less than enthusiastic about the network's coverage - something reflected in sparse audience figures in both the $\grave{A}$ Punt's election interviews and debate. One should not overlook the fact that the network is a new one and that many people have not yet made it part of their regular viewing. On the other hand, it is also true that $\grave{A}$ Punt has struggled to turn the public broadcaster into a trusted source of news for most Valencian citizens, as one can see from its screen share. That said, it was a stroke of bad luck for the network that the Valencian Regional Election coincided with the Spanish General Election for the first time ever. Not surprisingly, the latter hogged the limelight. The impact can be seen in the huge gap between $\grave{A}$ Punt's audiences and those for national networks. In the latter case, the TVE and Atresmedia debates on the $22^{\text {nd }}$ and $23^{\text {rd }}$ of April racked up 792000 (33.9\% audience share) and a million viewers (46.1\% audience share) respectively in The Valencian Country, overshadowing the regional broadcaster's paltry figures. This clearly shows that Spanish national politics is the priority for Valencian society.

Regarding the political interviews and to answer C1, the programme was seen as serving the general interest and mainly struck a delicate balance between neutralism and adversarialism as behoves a public broadcasting service. This brings it closer to the ideal of a news programme described earlier. This style stresses the highly institutional nature of the interviews and thus more closely reflects the balance struck between the powers wielded by the three actors involved: the media; politics; society. The journalist or interviewer was presented as a middle-man between the critical citizenry and the public TV broadcasting service (Lauerbach, 2004). Here there is little bias in either the purpose of the questions, the camera shots, or in other production values. The negative bias concerning Bonig or the positive bias concerning Martínez Dalmau is too slight to say that the network favoured one or other political party. Nevertheless, this may change in the future. One might say that the price of neutrality is eternal vigilance. Such interviews are commonplace on other channels, in which politicians tightly control the message they put over to viewers and journalists tend to bite their tongues rather than demand explanations or point out inconsistencies in a candidate's arguments. In any case, this is a novelty for Valencian public broadcasting, bearing in mind that such personal interviews were very much the exception on Canal 9.

In connection with the election debates in to answer $\mathrm{C} 2$, this is a very rigid, well established format. À Punt chose not to stray from what other regional and national networks do. It is a format in which the politician sets out his arguments virtually unchallenged (López García et al., 2018). The option of a five-way election debate used by the Valencian public TV network was dynamic and direct, fostering a 'conversation' among the candidates. All in all, it was a great advance on what Canal 9 used to churn out. That said, there is still room for improvement if the goal is to turn the event into a true clash between candidates in which proposals and objections are freely discussed, giving the TV audience an idea of each party's plans for the region. One of the problems that cannot be overcome is the presenter's control over the time each candidate speaks for. Maybe a running tally of the time each candidate talks might solve this issue. The way the network planned the event made for a more attractive TV debate in terms of image and pace, spinning an audiovisual tale that was more interesting and suggestive for the audience. Even so, a little more willingness to experiment with more daring debate formats would not go amiss. 
At the end of the day, we find that $\grave{A}$ Punt, Valencia's new government-owned broadcasting corporation, carried out its public mission to inform citizens on the 2019 Regional Election. It treated political parties and their candidates with neutrality and professionalism. At no point did we find data suggesting a TV station in cahoots with the present government or with Compromís in particular - the charge repeatedly levelled by the Opposition. In this respect, À Punt constantly negotiated with Valencian politicians in carrying out its reporting duties. While the network made all the decisions on technical TV matters, it let candidates play the leading role in interviews and debates, with politicians clearly being the ones in the saddle. This ongoing negotiation typifies the great mediatisation found in today's advanced societies (Casero Ripollés et al., 2014). Yet all in all, we find that $\grave{A}$ Punt was a little staid in its reporting, making do with reproducing the schemes and formulas used by other State and Regional broadcasters. The result was too much 'showmanship' and a fragmentation of the political discourse because of the 'infotainment' approach taken. This problem was particularly marked during the debate. Given that À Punt is a public service broadcaster, it behoves the network to show a little more leadership and innovation in conveying political information to citizens.

\section{BIBLIOGRAPHIC REFERENCES}

Abril, G. (1997). Teoría general de la información. Madrid: Cátedra.

Barreiro, X., Pereira, L. M., García, G. (2015). Los efectos sobre el voto de la campaña electoral en las elecciones europeas de 2014 en España. Revista Española de Ciencia Política, 39, 67-93.

Bennet, L. W. (2012). The Personalization of Politics: Political Identity, Social Media, and Changing Patterns of Participation. The Annals of the American Academy of Political and Social Science, 644(1), 20-39.

Benson, R. (2005). Mapping Field Variation: Journalism in France and The United States. In R. Benson and E. Neveu (ed.), In Bourdieu and the Journalistic Field (p. 85-112). Cambridge: Polity Press.

Berrocal Gonzalo, S. (co-ord.) (2017). Politainment: La política como espectáculo en los medios de comunicación. Valencia: Tirant Humanidades.

Berrocal, S., Redondo, M., Martín, V., Campos, E. (2014). La presencia del infoentretenimiento en los canales generalistas de la TDT. Revista Latina de Comunicación Social, 69, 85-109.

Blumler, J. and Kavanagh, D. (1999). The Third Age of Political Communication: Influences and Features. Political Communication, 16(3), 209-230.

Bolin, G. (2014). Television Journalism, Politics, and Entertainment: Power and Autonomy in the Field of Television Journalism. Television \& New Media, 15(4), 336-349.

Brants, K. (1998). Who's Afraid of Infotainment? European Journal of Communication, 13(3), 315-336.

Canel, M. J. (2006). Comunicación política: Una guía para su estudio y práctica. Madrid: Tecnos.

Casero Ripollés, A., Feenstra, R. A. and Tormey, S. (2016). Old and New Media Logics in an Electoral Campaign: The Case of Podemos and the Two-way Street Mediatization of Politics. The International Journal of Press/Politics 21(3), 378-397.

Casero Ripollés, A., Izquierdo Castillo, J. and Doménech Fabregat, H. (2014). From Watchdog to Watched Dog: Oversight and Pressures between Journalists and Politicians in the Context of Mediatization. Trípodos, 34, 23-40.

Casero Ripollés, A., Ortells Badenes, S. and Rosique Cedillo, G. (2017). La disolución de las viejas fronteras: La fusión entre información y entretenimiento en el periodismo político. In A. Casero Ripollés and P. López Rabadán (ed.), Periodistas y políticos en España (p. 119-142. Barcelona: UOC.

Castelló, E. (ed.) (2012). La mediatización del conflicto político: Discursos y narrativas en el contexto español. Barcelona: Laertes.

Chadwick, A. (2013). The Hybrid Media System. Politics and Power. New York: Oxford University Press. 
Clayman, S. E. (1992). Footing in the Achievement of Neutrality: The Case of News Interview Discourse. In P. Drew and J. Heritage (ed.), Talk at Work: Interaction in Institutional Settings (p. 163-198). Cambridge: Cambridge University Press.

Clayman, S. E. and Heritage, J. (2002). The News Interview: Journalists and Public Figures on the Air. Cambridge: Cambridge University Press.

Col-lectiu Blasco (2014). Reset RTVV: Per unes polítiques de comunicació al servei de la societat. Benicarló: Onada Edicions.

Conway, B. A., Kenski, K. and Wang, D. (2015). The Rise of Twitter in the Political Campaign: Searching for Intermedia Agenda-setting Effects in the Presidential Primary. Journal of Computer-Mediated Communication, 20, 363-380.

Cortés, L. and Bañón, A. M. (1997). Comentario lingüístico de textos orales II: El debate y la entrevista. Madrid: Arco Libros.

Couldry, N. and Hepp, A. (2013). Conceptualizing Mediatization: Contexts, Traditions, Arguments. Communication Theory, 23, 191-202.

Dayan, D. and Katz, E. (1995). La historia en directo: La retransmisión televisiva de los acontecimientos. Barcelona: Gustavo Gili.

De Moragas, M., Garitaonaindía, C. and López, B. (ed.) (1999). Televisión de proximidad en Europa: Experiencias de descentralización en la era digital. Bellaterra: Universitat Autònoma de Barcelona.

Delli Caprini, M. and Williams, B. A. (2011). After Broadcasting News. Cambridge: Cambridge University Press.

Edelman, M. (1988). Constructing the Political Spectacle. Chicago: Chicago University Press.

Flors, B., and Climent, V. (ed.) (2013). Adéu RTVV: Crònica del penúltim fracàs de la societat valenciana. Valencia: Publicacions de la Universitat de València.

Francés i Domènec, M. (2014). La TV local de proximidad: Historia de un fracaso como servicio público en la teledifusión digital valenciana. In A. Boix and J. M. Vidal (ed.), La nueva regulación del audiovisual: Medios, derechos y libertades (p. 139-152). Pamplona: Aranzadi.

García, J. (2015). La cobertura mediática de los debates electorales en España. Revista Española de Ciencia Política, $38,135-161$.

Hallin, D. and Mancini, P. (2004). Comparing Media Systems: Three Models of Media and Politics. New York: Cambridge University Press.

Harrington, S. (2008). Popular News in the $21^{\text {st }}$ Century: Time for a New Critical Approach? Journalism, 9(3), $266-284$.

Hartley, J. (2000). Los usos de la televisión. Barcelona: Paidós.

Hepp, A., Hjarvard, S. and Lundby, K. (2015). Mediatization: Theorizing the Interplay between Media, Culture and Society. Media, Culture \& Society, 37(2), 314-324.

Heritage, J. and Clayman, S. (2010). Talk in Action: Interactions, Identities and Institutions. Chichester: Wiley-Blackwell.

Heritage J. and Greatbatch, D. (1991). On the Institutional Character of Institutional Talk: The Case of News Interviews. In D. Boden and D. H. Zimmerman (ed.), Talk and Social Structure: Studies in Ethnomethodology and Conversation Analysis (p. 93-137). Cambridge: Polity Press.

Holtz Bacha, Ch. (2003). Comunicación política: Entre la privatización y la espectacularización. Diálogo Político, 1, 137-154.

Humanes, M. L. (2014). Exposición selectiva y partidismo de las audiencias en España: El consumo de información política durante las campañas electorales de 2008 y 2011. Palabra Clave, 17(3), 773-802.

Langer, J. (2000). La televisión sensacionalista: El periodismo popular y las «otras noticias». Barcelona: Paidós.

Lauerbach G. (2004). Political Interviews as Hybrid Gener. Text, 24(3), 353-397.

León, B. (2010). Introducción: Información y espectáculo en un nuevo ecosistema informativo. In B. León (co-ord.), Informativos para la televisión del espectáculo (p. 17-29). Seville/Zamora: Social Communication.

López García, G., and Valera Ordaz, L. (ed.) (2017). Pantallas electorales. El discurso de partidos, medios y ciudadanos en la campaña de 2015. Barcelona: UOC.

López García, G., Llorca Abad, G., Valera Ordaz, L. and Peris Blanes, A. (2018). Los debates electorales, ¿el último reducto frente a la mediatización? Un estudio de caso de las elecciones generales españolas de 2015. Palabra Clave, 21(3), 772-797. DOI: 10.5294/pacla.2018.21.3.6

Maarek, Ph. J. (2009). Marketing político y comunicación: Claves para una buena información política. Barcelona: Paidós. 
Marchetti, D. (2005). Subfields of Specialized Journalism. In R. Benson and E. Neveu (ed.), Bourdieu and the Journalistic Field (p. 64-82). Cambridge: Polity Press.

Marín Pérez, B. (2003). Comunicación política en televisión y nuevos medios. In S. Berrocal (ed.), Debates electorales por televisión (p. 207-243). Barcelona: Ariel.

Marzal Felici, J. and Soler Campillo, M. (2016). Retos de la futura radiotelevisión pública de la Comunidad Valenciana: Un espacio para la aplicación de buenas prácticas públicas. In M. Francés i Domènec and G. Orozco Gómez (coord.), Nuevos modelos mediáticos: Diversidad, usuarios y ventanas (p. 121-134). Madrid: Editorial Síntesis.

Marzal, J. J. and Zallo, R. (2016). Las televisiones públicas de proximidad ante los retos de la sociedad digital. Communication \& Society, 29(4), 1-7.

Marzal, J. J., Casero, A. and Izquierdo, J. (ed.) (2015). La crisis de la televisión pública: El caso de RTVV y los retos de una nueva gobernanza. Valencia: Publicacions de la Universitat de València.

Mazzoleni, G. (2010). La comunicación política. Madrid: Alianza Editorial.

Mazzoleni, G. and Schulz, W. (1999). Mediatization of Politics: A Challenge for Democracy? Political Communication, 16(3), 247-261.

Mazzoleni, G. and Sfardini, A. (2009). Politica Pop: De 'Porta a Porta' a 'L'isola dei famosi'. Bologna: Il Mulino.

McChesney, R. W. (1999). Rich Media, Poor Democracy: Communication Politics in Dubious Times. Urbana: University of Illinois Press.

Montgomery, M. (2008). The Discourse of the Broadcast News Interview. Journalism Studies, 9(2), $260-277$.

Neuendorf, K. A. (2002). The Content Analysis Guidebook. Thousand Oaks: SAGE.

Nimmo, D. (1995). The Formation of Candidate Images during Presidential Campaigns. Candidate Images in Presidential Elections, 51-63

Pellisser, N. and Pineda, A. (2014). Información política televisiva y espectacularización: Un análisis comparativo de programas informativos y de infoentretenimiento. Estudios sobre el Mensaje Periodístico, 20(2), 821-839.

Peris Blanes, À. and López Rico, C. M. (2017). Los programas de entretenimiento: espectáculo y emoción en la comunicación política española. In G. López García and L. Valera Ordaz (ed.), Pantallas electorales: El discurso de partidos, medios y ciudadanos en la campaña de 2015 (p. 129-151). Barcelona: UOC.

Peris Blanes, À., Llorca Abad, G., Sánchez Castillo, S., López Rico, C. M. (2017). La televisión y la formación de la opinión pública: informativos y debates electorales. In G. López García and L. Valera Ordaz (ed.), Pantallas Electorales. El discurso de partidos, medios y ciudadanos en la campaña de 2005 (p. 101-128). Barcelona: UOC.

Peris, À. (2015). Canal 9 i el sector audiovisual valencià: Una relació traumàtica. In J. Rodríguez and Santonja (ed.), Present, passat i futur d'RTVV (p. 63-99). Valencia: Uno and Cero Ediciones.

Pomerantz, A. (1984). Agreeing and Disagreeing with Assessments: Some Features of Preferred/ dispreferred Turn Shapes. In J. M. Atkinson and J. Heritage (ed.), Structures of Social Action: Studies in Conversation Analysis (p. 57-101). Cambridge: Cambridge University Press.

Redondo, M. and Campos Domínguez, E. (2015). Implicaciones éticas del infoentretenimiento televisivo. Comunicació. Revista de Recerca i d'Anàlisi, 32(1), 73-89.

Roca Cuberes, C. (2014). Political Interviews in Public Television and Commercial Broadcasters: A Comparison. Discourse and Communication, 8(2), 155-179.

Sánchez Castillo, S. (2018). Audiovisual Politeness in TV Political Interviews. Communication \& Society, 31(2), 137-152.

Sánchez Duarte, J. M. (2016). La red como espacio para la militancia política: Tecnología y participación en campaña electoral. Communication \& Society, 29(3), 33-47.

Shirky, C. (2008). Here Comes Everybody: The Power of Organizing without Organizations. London: Allan Lane.

Strömback, J. (2008). Four Phases of Mediatization: An Analysis of Mediatization of Politics. The International Journal of Press/Politics, 13(3), 228-246.

Thussu, D. K. (2007). News as Entertainment. London: SAGE.

Vaccari, C. (2013). Digital Politics in Western Democracies: A Comparative Study. Baltimore: John Hopkins University Press.

Vaccari, C., Chadwick, A. and O'Loughlin, B. (2015). Dual Screening the Political: Media Events, Social Media, and Citizen Engagement. Journal of Communication, 65, 1041-1061.

Valera Ordaz, L. (2015). La influencia de los partidos políticos españoles en las agendas de medios y blogs durante la campaña electoral de 2011. Communication \& Society, 28(3), 115-135. 
Wieten J. and Pantti M. (2005). Obsessed with the Audience: Breakfast Television Revisited. Media, Culture \& Society, 27(1), 21-39.

Xambó, R. (2013). RTVV: De l'esperança a la manipulació i el saqueig. L'Espill, 43, 88-97.

Zallo, R. (2011). Estructuras de la comunicación y de la cultura: Políticas para la era digital. Barcelona: Gedisa.

\section{BIOGRAPHICAL NOTE}

\section{Àlvar Peris Blanes}

Associate Professor of Audiovisual Communication at Universitat de València. His main research interests cover the link between identities and the media, and in analysing politics and television entertainment. Peris has published many works on communication, cultural studies, and history. He is a researcher in the Mediaflows R\&D project.

\section{Benjamín Marín Pérez}

Marín holds a PhD in Journalism, an EMBA, and a Master's Degree in Scientific Communication. He is Associate Professor of Journalism at Universitat de València. Marín was Director of Communications for the Valencian Pavilion at Expo'92. He worked as journalist at RTVV (Radiotelevisión Valenciana) and is currently a News and Sports journalist at À Punt Mèdia. Marín was awarded the ONDAS Prize in 2007. His research focuses on television, political communication, and organisations' digital communication.

\section{Sebastián Sánchez Castillo}

Sánchez holds a PhD in Audiovisual Communication. He is Tenured Professor at Universitat de València, and has published many studies on audiovisual persuasion, empathy in audiovisual fiction, transmedia and production processes. Sánchez has been both a Guest Professor in the teaching and research fields at universities in Argentina, Chile, Italy, Portugal, and The United Kingdom. He also worked at RTVV (Radiotelevisión Valenciana) from 1989 to 2013. 